r ScIDice

\section{International Journal of Dentistry and Oral Science (IJDOS)}

ISSN: $2377-8075$

\title{
Resin Infiltration
}

Research Article

Astha Bramhecha ${ }^{1}$, Jogikalmat Krithikadatta ${ }^{2 *}$

${ }^{1}$ Department of Conservative Dentistry and Endodontics, Saveetha Institute of Medical and Technical Science, Saveetha University, Chennai 600077, India.

${ }^{2}$ Head of Department, Department of Cariology, Saveetha Dental College and Hospitals, Saveetha Institute of Medical and Technical Science, Saveetha University, Chennai 600077, India.

\section{Abstract}

The resin infiltration technology is unique and a minimally invasive treatment for the arrest of carious lesions. The resin material blocks the porosity in the lesion, fills the pores of the tooth fully and prevents caries from progressing. The special resins, optimised to penetrate quickly, penetrate to a considerable depth. Resin infiltration is indicated to mask white spot lesions and early enamel caries. Using Icon leads to masking of white spot lesions with minimal destruction of teeth and an aesthetic outcome. It has been found to be a more effective mode of treatment than microabrasion.It differs from pit and fissure sealants in that it creates a barrier within the carious lesion rather than on the lesion's surface.

Keywords: Resin Infiltration; White Spot Lesions; Minimally Invasive Dentistry.

\section{Introduction}

White spot lesions are enamel lesions that are opaque and chalky white in appearance. It may be caused by idiopathic causes, early carious lesions or fluorosis. Early enamel lesions and white spot lesions are likely the first signs of dental caries. They may appear on any tooth surface in the oral cavity where a microbial biofilm has been allowed to form and persist for a long time.[1, 2] Noninvasive treatment of non-cavitated carious lesions, also known as original or early carious lesions, has been suggested in many ways. Remineralization of the lesion with fluoride is one of them.[3] Usage of casein phosphopeptide amorphous calcium phosphate or topical sealants for occlusal lesions are two other options. [4, 5]

The penetration of subsurface lesions with low-viscous light-curing resins may be a successful alternative therapy for the arrest of carious lesions. Since the porosities in enamel caries serve as diffusion pathways for acids and dissolved minerals, resin infiltration of these lesions can obstruct these pathways, halting caries progression. Several studies have shown that commercially available adhesives and fissure sealants can penetrate artificial caries lesions.
[6-8] Therefore based on experiments conducted by Robinson et al to stop carious lesions, an alternative solution for superficial sealing may be by infiltrating these pores with resorcinol-formaldehyde resins. This concept has been adapted and commercially introduced in Germany for the management of smooth surface and proximal non-cavitated caries lesions, in which the porosities of the enamel lesion are infiltrated with a low viscosity resin, forming a diffusion barrier within the lesion without establishing any material on the enamel surface. This technique is known as "resin infiltration."[9-19]

It's possible caries-inhibiting action is dependent on the occlusion of the pores within the body of the caries lesion, as opposed to the sealing of caries lesions, which is dependent on the external occlusion of the lesion with the sealant substance. $[12,13]$

Previously our team has a rich experience in working on various research projects across multiple disciplines [14-28]. Now the growing trend in this area motivated us to pursue this project.

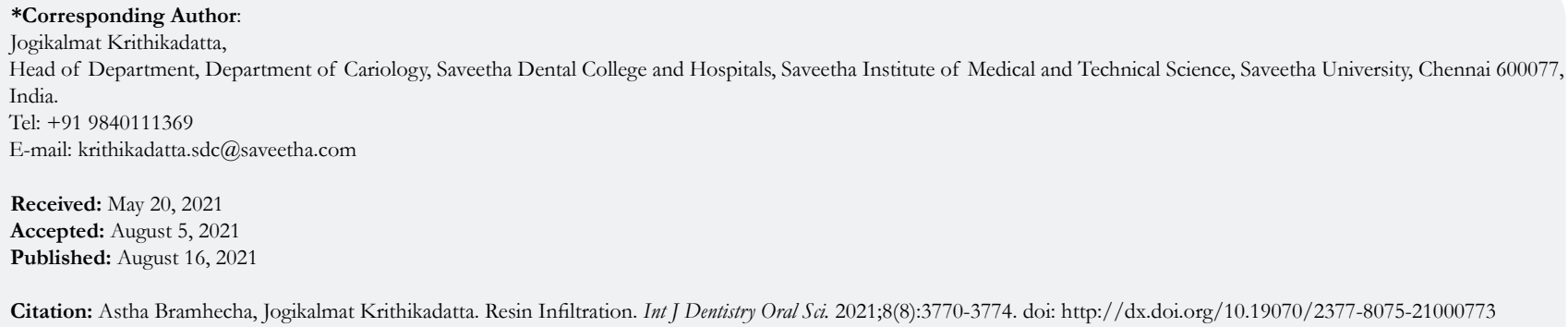

Copyright: Jogikalmat Krithikadatta 2021 . This is an open-access article distributed under the terms of the Creative Commons Attribution License, which permits unrestricted use, distribution and reproduction in any medium, provided the original author and source are credited. 


\section{Concept}

Resin penetration technology is a minimally invasive technique for reinforcing, filling, and stabilising demineralized enamel without drilling or compromising stable tooth structure; it may be used to handle proximal and smooth surface caries up to the initial one third of dentin.It slows down the development of the lesion and extends the life of the tooth. It is a viable alternative to microabrasion and other restorative therapies for cariogenic white spot lesions. Once the resin has penetrated the white spot lesion, it takes on the form of the protective enamel around it. As a result, resin infiltration can be used to conceal aesthetically unappealing white spot lesions on the buccal surfaces.It is a new technology that appears to fill the difference between minimally invasive and non-invasive care of early dental caries, delaying the need for a restoration as long as possible.[29]

Resin penetration works through capillary action to perfuse the porous enamel with resin, effectively stopping the development of the lesion by occluding the microporosities that enable acids and dissolved materials to diffuse. The aim of this procedure is to create a diffusion barrier inside the lesion rather than on the surface.[30] It is marketed as Icon ${ }^{\circledR}$ (DMG America Company, Englewood, NJ).

\section{Resin Infiltration Technique}

ICON etchant $\rightarrow$ ICON dry $\rightarrow$ ICON infiltrant $\rightarrow$ Light curing the infiltrant [31].

Icon ${ }^{\circledR}$ comes in two varieties: proximal and vestibular surface kits. Both are used in the same way, with the exception that proximal lesion therapy requires isolation. Since the surface layer of enamel caries lesions has a lower pore volume than the lesion body under it, it acts as a deterrent to resin penetration. As a result, a preparation process is needed, in which the teeth's surface is cleaned and prepared.[32]

The 45-micron thick surface layer of the lesion was almost entirely removed with a 15 percent hydrochloric acid solution (icon etch) added for 90-120 seconds.[32]

The surface is desiccated using the ethanol wet bonding process, which involves adding 99\% ethanol (Icon Dry) for 30 seconds and then air drying. It's built on the idea that it will coax hydrophobic monomers into demineralized wet enamel or dentine, improving the effectiveness of hydrophobic infiltrate penetration (TEGDMA), resulting in a well-defined, resin-infiltrated layer.[33, 34]

The next step is to penetrate resin into the porosities formed during intercrystalline enamel dissolution after the surface layer of the carious lesion has been removed. In comparison to dental adhesives, unfilled resin infiltrants have been shown to have a deeper action into carious lesions.[35] TEGDMA resin infiltrant was shown to penetrate deeper than other formulations of infiltrants. [36]

A microbrush is used to apply icon infiltrant, which is made up of tetraethylene glycol dimethacrylate(TEGDMA), to the lesion surface and allow it to penetrate for three minutes. A cotton roll is used to extract the excess, which is then light cured. A one- minute application is repeated, and the resin is then light cured once more, after which excess resin is removed and the surface is polished. [37, 38]

\section{Indications}

The infiltration method has been suggested for covering white spots associated with the non carious conditions like fluorosis, and it tends to provide patients acceptable cosmetic outcomes. [39] The procedure is mainly used to treat early proximal lesions in almost all age groups. The tissue lost due to demineralisation is substituted by infiltrated resin below a depth of 800 microns[31]. The procedure may also be used to treat carious lesions on nonproximal smooth surfaces, such as opaque white lesions around orthodontic instruments in a high-caries-risk oral setting, if they are not cavitated and surrounded by healthy enamel. The procedure not only stabilises the lesion, but it also improves the condition of the tooth.[40] Other indications for resin infiltration, relating to the presence of tissue porosity, include amelogenesis imperfecta, molar incisor hypomineralization, and white spots. $[12,13]$

Initial caries and developmental defects of enamel have a white spot appearance due to subsurface porosity in the enamel under a well-mineralized surface layer.[41, 42] Because of the various refractive indices of enamel, water, and air, white spot lesions are more visible when the teeth are dry. The refractive index of sound enamel is 1.62. When enamel is demineralized, it becomes porous. The lesions will appear opaque in comparison to the sound tissue if the pores inside the lesion are filled with water (refractive index: 1.33). As the pores are dried, the water in the pores is replaced with air (refractive index 1.0), making the lesion more visible. [43] When the microporosities are filled with infiltrant resin, the refractive indices increase to 1.52 , the difference in refractive index between the infiltrated lesion and the surrounding sound enamel is negligible, and the lesions resemble the sound enamel.

\section{Advantages}

Infiltrating resins have paved a new direction in the treatment of early carious lesions, aligning with the physician's aim of healing without causing damage. This technique isn't intrusive and preserves the tooth's structure and mechanically helps in the stabilization of demineralized enamel.[40] Resin infiltration technique promotes enhanced penetration into porous, demineralized areas thus stopping or slowing the progression of the lesion. Thus reducing secondary caries risk in a caries controlled environment. With the use of this technique postoperative sensitivity and pulpal inflammation are not a concern as well as gingivitis and periodontitis are less likely to occur. When used as a "masking resin ", the aesthetic result was significantly improved.[29] It helps to postpone the need for restorative action for longer periods of time. [11] This therapy may be completed in one treatment session, as opposed to remineralization techniques that could include several follow-up sessions, which is vital for patients, especially children and their parents.

Resin infiltration seems to be especially well suited to proximal lesions where, even by using micro-invasive methods of preparation such as sono-abrasion, the ratio of normal tissue to carious tissue results in a substantial reduction of healthy tissue in order 
to obtain access to the lesion.[40] In comparison to microabrasion or restoration, resin infiltration is much less invasive. [32, 44-46] Infiltrant resin, unlike fluoride or CPP-ACP remineralization, can enhance colour even in deeper lesions since it penetrates deeper lesions and the effect is visible immediately after treatment. $[35,47,48]$

\section{Limitations Of Resin Infiltration}

The outcome's long-term viability after resin infiltration is determined by the lesion's environment. Caries inhibition is sustained in a weakly demineralizing setting, but demineralisation is likely to continue or recur at the periphery of the resin infiltrated region in a patient at unregulated risk of caries. The approach would not eliminate the need for adequate caries risk assessment and patient care.[40] In some cases, the masking effect of resin infiltration was drastic, although in others, it was not. Continuous clinical and experimental experiments need to be conducted to track the technique's long-term colour consistency.

Cavitated lesions (code 5) displayed slightly less resin infiltration than non-cavitated lesions (codes 2 and 3), and the resin was unable to fill the cavities, according to a recent in vitro analysis measuring the degree of resin penetration according to ICDAS codes. [49] As a result, the procedure is not recommended for the treatment of cavitated lesions.

ICON is based on the infiltration principle which involves a very dry area. Additional precautions must be taken to dry the lesion in addition to maintaining the air free of moisture. This is achieved by treating the lesion area with alcohol, which causes evaporation of the water within the porosities, preventing the infiltration process. Therefore inefficient isolation may affect the success of the treatment.[50]

\section{Evidence Proving Concept Of Resin Infiltration}

Commercially available adhesives and fissure sealants have been shown in several studies to penetrate artificial caries lesions. [51, $8,52]$ Infiltrated artificial lesions do not advance in a cariogenic setting, according to studies. [53,54] Under cariogenic conditions in situ, resin penetration is effective in preventing further demineralization of artificial enamel caries lesions. [55] It is not appropriate to transfer results from artificial to natural lesions because there are significant structural variations between them.[56]

A randomized split-mouth placebo-controlled clinical trial by $\mathrm{S}$. Paris et al about effect of resin infiltration of proximal carious lesions on caries progression stated that infiltration of interproximal caries lesions is efficacious in reducing lesion progression.[57] Another study by S. Paris et al, aimed to evaluate the penetration of a conventional adhesive into natural enamel caries after pretreatment with two different etching gels in vitro. It was found that etching with $15 \%$ hydrochloric acid gel is more suitable than $37 \%$ phosphoric acid gel as a pre-treatment for caries lesions intended to be infiltrated. [56]

Resins with higher penetration coefficients (infiltrants) show superior ability to penetrate natural lesions compared with resins with lower penetration coefficients in a study by H. Meyer-Lueckel et al.[35] The objective of one in vitro study was to evaluate the ability of one commercial and five experimental infiltrating resins (infiltrants) to camouflage enamel white spot lesions immediately after resin infiltration and after a staining period. In vitro, resin penetration was shown to effectively mask artificial caries lesions. Polished infiltrated lesions were found to be staining resistant. The refractive indices of infiltrants and masking performance have a mild association, but clinical factors (lesion depth and behavior, complete infiltration, resin colour) may be more significant.[58]According to Senestraro and colleagues' , resin penetration enhanced the clinical appearance of white-spot lesions while also reducing their size. Furthermore, during the eight-week study period, the clinical appearance of teeth with white-spot lesions restored with resin infiltration remained stable.[12]

Clinical assessment of the effectiveness of masking white spot enamel lesions using a resin infiltration in teeth with developmental defect of enamel and post orthodontic decalcification determined that the colour differences between the sound and white spot enamel decreased significantly after infiltration. [37]

Caries infiltration appears to be a promising treatment option for non cavitated caries lesions. Unlike fissure sealing, which places the diffusion barrier on top of the (lesion) surface, infiltration aims to position the diffusion barrier within the lesion by replacing missing minerals with resin. Over an 18-month observation period, a clinical trial observed a substantially reduced but still relatively high (43.5\%) lesion development when proximal enamel lesions were superficially sealed with an adhesive.[59] There were no major variations in lesion progression between the sealed and control groups in another clinical study by Gomez et al.[60] Treatment failures, according to the above authors, may be due to insufficient sealing or sealant disintegration over time. Furthermore, laboratory tests revealed that unfilled resins are less resistant to mechanical and chemical stress.[61] As a result, it's unclear if superficial smooth-surface sealing with unfilled resins should be used in everyday practise.

In comparison to sealers, the infiltration treatment can provide a number of benefits. Proximal lesions may be penetrated with application strips that are coated on one side, with limited need for tooth separation and no special protection for the adjacent tooth. The infiltration technique removes excess resin from the tooth surface before light-curing, making clinical application much easier. Furthermore, no sealant margins are formed on the tooth surface with this procedure, which could promote plaque accumulation and cause periodontal inflammation. Infiltration of the porous lesion structures may also help to stabilise the lesion mechanically and avoid cavitation.

\section{Conclusion}

Based on the available evidence, resin infiltration of enamel lesions should aim to halt the development of white spot lesions. Combining this minimally invasive approach with a comprehensive caries remineralization programme can provide therapeutic benefits while also substantially reducing long-term restorative needs and costs, complementing the principle of minimal intervention dentistry. Although it showed convincing results, more clinical trials are required for definitive results.

Our institution is passionate about high quality evidence based 
research and has excelled in various fields [62-72].

\section{Disclosure Statement}

The authors declare no potential conflicts of interest with respect to the authorship and/or publication of this article.

\section{Author Contributions}

Astha Bramhecha, contributed to conception, design and concise drafting of the manuscript. Krithika Datta critically revised the manuscript. The authors give final approval and agrees to be accountable for all aspects of the work.

\section{References}

[1]. Son JH, Hur B, Kim HC, Park JK. Management of white spots: resin infiltration technique and microabrasion. J Korean Acad Conserv Dent. 2011 Jan 1;36(1):66-71.

[2]. Chang HS, Walsh LJ, Freer TJ. Enamel demineralization during orthodontic treatment. Aetiology and prevention. Aust Dent J. 1997 Oct;42(5):322-7.

[3]. Cury JA, Tenuta LM. Enamel remineralization: controlling the caries disease or treating early caries lesions?. Braz. Oral Res. 2009 (Suppl);23:23-30.

[4]. Cochrane NJ, Shen P, Byrne SJ, Walker GD, Adams GG, Yuan Y, et al. Remineralisation by chewing sugar-free gums in a randomised, controlled in situ trial including dietary intake and gauze to promote plaque formation. Caries Res. 2012;46(2):147-55.Pubmed PMID: 22488208.

[5]. Griffin SO, Oong E, Kohn W, Vidakovic B, Gooch BF, CDC Dental Sealant Systematic Review Work Group. The effectiveness of sealants in managing caries lesions. J. Dent. Res. 2008 Feb;87(2):169-74.

[6]. Dayila JM, Buonocore MG, Greeley CB, Provenza DV. Adhesive penetration in human artificial and natural white spots. J Dent Res. 1975 Sep;54(5):9991008 .

[7]. Robinson C, Brookes SJ, Kirkham J, Wood SR, Shore RC. In vitro studies of the penetration of adhesive resins into artificial caries-like lesions. Caries Res. 2001 Mar-Apr;35(2):136-41.Pubmed PMID: 11275674.

[8]. Meyer-Lueckel H, Paris S, Mueller J, Cölfen H, Kielbassa AM. Influence of the application time on the penetration of different dental adhesives and a fissure sealant into artificial subsurface lesions in bovine enamel. Dent Mater. 2006 Jan;22(1):22-8.Pubmed PMID: 16040112.

[9]. Doméjean S, Ducamp R, Léger S, Holmgren C. Resin infiltration of non-cavitated caries lesions: a systematic review. Med Princ Pract. 2015;24(3):21621.

[10]. Robinson C, Hallsworth AS, Weatherell JA, Künzel W. Arrest and control of carious lesions: a study based on preliminary experiments with resorcinolformaldehyde resin. J Dent Res. 1976 Sep-Oct;55(5):812-8.Pubmed PMID: 823185.

[11]. Paris S, Meyer-Lueckel H, Cölfen H, Kielbassa AM. Resin infiltration of artificial enamel caries lesions with experimental light curing resins. Dent. Mater. J. 2007;26(4):582-8

[12]. Senestraro SV, Crowe JJ, Wang M, Vo A, Huang G, Ferracane J, et al. Minimally invasive resin infiltration of arrested white-spot lesions: a randomized clinical trial. J Am Dent Assoc. 2013 Sep 1;144(9):997-1005.

[13]. Muñoz MA, Arana-Gordillo LA, Gomes GM, Gomes OM, Bombarda NH, Reis A, et al. Alternative esthetic management of fluorosis and hypoplasia stains: blending effect obtained with resin infiltration techniques. J Esthet Restor Dent. 2013 Feb;25(1):32-9.

[14]. Govindaraju L, Gurunathan D. Effectiveness of Chewable Tooth Brush in Children-A Prospective Clinical Study. J Clin Diagn Res. 2017 Mar;11(3):ZC31-ZC34.Pubmed PMID: 28511505.

[15]. Christabel A, Anantanarayanan P, Subash P, Soh CL, Ramanathan M, Muthusekhar MR, et al. Comparison of pterygomaxillary dysjunction with tuberosity separation in isolated Le Fort I osteotomies: a prospective, multi-centre, triple-blind, randomized controlled trial. Int J Oral Maxillofac Surg. 2016 Feb;45(2):180-5.Pubmed PMID: 26338075.

[16]. Soh CL, Narayanan V. Quality of life assessment in patients with dentofacial deformity undergoing orthognathic surgery--a systematic review. Int J Oral Maxillofac Surg. 2013 Aug;42(8):974-80.Pubmed PMID: 23702370.

[17]. Mehta M, Deeksha, Tewari D, Gupta G, Awasthi R, Singh H, et al. Oligonucleotide therapy: An emerging focus area for drug delivery in chronic inflammatory respiratory diseases. Chem Biol Interact. 2019 Aug 1;308:206215.Pubmed PMID: 31136735.
[18]. Ezhilarasan D, Apoorva VS, Ashok Vardhan N. Syzygium cumini extract induced reactive oxygen species-mediated apoptosis in human oral squamous carcinoma cells. J Oral Pathol Med. 2019 Feb;48(2):115-121.Pubmed PMID: 30451321.

[19]. Campeau PM, Kasperaviciute D, Lu JT, Burrage LC, Kim C, Hori M, et al. The genetic basis of DOORS syndrome: an exome-sequencing study. Lancet Neurol. 2014 Jan;13(1):44-58.Pubmed PMID: 24291220.

[20]. Sneha S. Knowledge and awareness regarding antibiotic prophylaxis for infective endocarditis among undergraduate dental students. Asian J Pharm Clin Res. 2016 Oct 1:154-9.

[21]. Christabel SL, Linda Christabel S. Prevalence of type of frenal attachment and morphology of frenum in children, Chennai, Tamil Nadu. World J Dent. 2015 Oct;6(4):203-7.

[22]. Kumar S, Rahman R. Knowledge, awareness, and practices regarding biomedical waste management among undergraduate dental students. Asian J Pharm Clin Res. 2017;10(8):341.

[23]. Sridharan G, Ramani P, Patankar S. Serum metabolomics in oral leukoplakia and oral squamous cell carcinoma. J Cancer Res Ther. 2017 Jul 1;13(3):556561.

[24]. Ramesh A, Varghese SS, Doraiswamy JN, Malaiappan S. Herbs as an antioxidant arsenal for periodontal diseases. J Intercult Ethnopharmacol. 2016 Jan 27;5(1):92-6.Pubmed PMID: 27069730.

[25]. Thamaraiselvan M, Elavarasu S, Thangakumaran S, Gadagi JS, Arthie T. Comparative clinical evaluation of coronally advanced flap with or without platelet rich fibrin membrane in the treatment of isolated gingival recession. J Indian Soc Periodontol. 2015 Jan;19(1):66-71.

[26]. Thangaraj SV, Shyamsundar V, Krishnamurthy A, Ramani P, Ganesan K, Muthuswami M, et al. Molecular Portrait of Oral Tongue Squamous Cell Carcinoma Shown by Integrative Meta-Analysis of Expression Profiles with Validations. PLoS One. 2016 Jun 9;11(6):e0156582.Pubmed PMID: 27280700.

[27]. Ponnulakshmi R, Shyamaladevi B, Vijayalakshmi P, Selvaraj J. In silico and in vivo analysis to identify the antidiabetic activity of beta sitosterol in adipose tissue of high fat diet and sucrose induced type- 2 diabetic experimental rats. Toxicol Mech Methods. 2019 May;29(4):276-290.Pubmed PMID: 30461321.

[28]. Ramakrishnan M, Shukri M. Fluoride, Fluoridated Toothpaste Efficacy And Its Safety In Children-Review. Int. J. Pharm. Sci. Res. 2018 Oct $1 ; 10(04): 109-14$

[29]. Kielbassa AM, Muller J, Gernhardt CR. Closing the gap between oral hygiene and minimally invasive dentistry: a review on the resin infiltration technique of incipient (proximal) enamel lesions. Quintessence Int. 2009 Sep;40(8):663-81.Pubmed PMID: 19639091.

[30]. Manoharan V, Arun Kumar S, Arumugam SB, Anand V, Krishnamoorthy S, Methippara JJ. Is Resin Infiltration a Microinvasive Approach to White Lesions of Calcified Tooth Structures?: A Systemic Review. Int J Clin Pediatr Dent. 2019 Jan-Feb;12(1):53-58.Pubmed PMID: 31496574.

[31]. Kugel G, Arsenault P, Papas A. Treatment modalities for caries management, including a new resin infiltration system. Compend Contin Educ Dent. 2009 Oct;30 Spec No 3:1-10; quiz 11-2.Pubmed PMID: 19894293.

[32]. Meyer-Lueckel H, Paris S, Kielbassa AM. Surface layer erosion of natural caries lesions with phosphoric and hydrochloric acid gels in preparation for resin infiltration. Caries Res. 2007;41(3):223-30.

[33]. de Barros L, Apolonio FM, Loguercio AD, de Saboia V. Resin-dentin bonds of etch-and-rinse adhesives to alcohol-saturated acid-etched dentin. J Adhes Dent. 2013 Aug;15(4):333-40.Pubmed PMID: 23534031.

[34]. Li F, Liu XY, Zhang L, Kang JJ, Chen JH. Ethanol-wet bonding technique may enhance the bonding performance of contemporary etch-and-rinse dental adhesives. J Adhes Dent. 2012 Apr;14(2):113-20.Pubmed PMID: 21734972.

[35]. Meyer-Lueckel H, Paris S. Improved resin infiltration of natural caries lesions. J Dent Res. 2008 Dec;87(12):1112-6.

[36]. Meyer-Lueckel H, Paris S. Infiltration of natural caries lesions with experimental resins differing in penetration coefficients and ethanol addition. Caries Res. 2010;44(4):408-14.

[37]. Kim S, KIM EY, JEONG TS, KIM JW. The evaluation of resin infiltration for masking labial enamel white spot lesions. Int. J. Paediatr. Dent. 2011 Jul;21(4):241-8

[38]. Guerrieri A, Gaucher C, Bonte E, Lasfargues JJ. Minimal intervention dentistry: part 4. Detection and diagnosis of initial caries lesions. Br Dent J. 2012 Dec;213(11):551-7.Pubmed PMID: 23222326.

[39]. Paris S, Meyer-Lueckel H. Masking of labial enamel white spot lesions by resin infiltration--a clinical report. Quintessence Int. 2009 Oct;40(9):713-8. Pubmed PMID: 19862396.

[40]. Lasfargues JJ, Bonte E, Guerrieri A, Fezzani L. Minimal intervention dentistry: part 6. Caries inhibition by resin infiltration. Br Dent J. 2013 Jan;214(2):53-9.Pubmed PMID: 23348449. 
[41]. Newbrun E, Brudevold F. Studies on the physical properties of fluorosed enamel-I: microradiographic studies. Arch. Oral Biol. 1960 May 1;2(1):15IN1.

[42]. Fejerskov O, Yaeger JA, Thylstrup A. Microradiography of the effect of acute and chronic administration of fluoride on human and rat dentine and enamel. Arch Oral Biol. 1979;24(2):123-30.Pubmed PMID: 299137.

[43]. Deery C, Hosey MT, Waterhouse P. Paediatric cariology. Quintessence Publishing Co., Ltd; 2019 Mar 19.

[44]. Malterud MI. Minimally invasive restorative dentistry: a biomimetic approach. Pract Proced Aesthet Dent. 2006 Aug 1;18(7):409-414.

[45]. Stahl J, Zandona AF. Rationale and protocol for the treatment of non-cavitated smooth surface carious lesions. Gen Dent. 2007 Mar-Apr;55(2):105-11. Pubmed PMID: 17333980.

[46]. Tong LS, Pang MK, Mok NY, King NM, Wei SH. The effects of etching, micro-abrasion, and bleaching on surface enamel. J Dent Res. 1993 Jan;72(1):67-71.Pubmed PMID: 8418110.

[47]. Willmot DR. White lesions after orthodontic treatment: does low fluoride make a difference?. J Orthod. 2004 Sep 1;31(3):235-42.

[48]. Ardu S, Castioni NV, Benbachir-Hassani N, Krejci I. Minimally invasive treatment of white spot enamel lesions. Quintessence Int. 2007;38(8):633636.

[49]. Paris S, Bitter K, Naumann M, Dörfer CE, Meyer-Lueckel H. Resin infiltration of proximal caries lesions differing in ICDAS codes. Eur. J. Oral Sci. 2011 Apr;119(2):182-6.

[50]. Jia L, Stawarczyk B, Schmidlin PR, Attin T, Wiegand A. Influence of caries infiltrant contamination on shear bond strength of different adhesives to dentin. Clin Oral Investig. 2013 Mar;17(2):643-8.Pubmed PMID: 22526893.

[51]. Robinson C, Brookes SJ, Kirkham J, Wood SR, Shore RC. In vitro studies of the penetration of adhesive resins into artificial caries-like lesions. Caries Res. 2001 Mar-Apr;35(2):136-41.Pubmed PMID: 11275674.

[52]. Schmidlin PR, Zehnder M, Pasqualetti T, Imfeld T, Besek MJ. Penetration of a bonding agent into De- and remineralized enamel in vitro. J Adhes Dent. 2004 Summer;6(2):111-5.Pubmed PMID: 15293419.

[53]. Mueller J, Meyer-Lueckel H, Paris S, Hopfenmuller W, Kielbassa AM. Inhibition of lesion progression by the penetration of resins in vitro: influence of the application procedure. Oper Dent. 2006 May;31(3):338-45.

[54]. Paris S, Meyer-Lueckel H, Mueller J, Hummel M, Kielbassa AM. Progression of sealed initial bovine enamel lesions under demineralizing conditions in vitro. Caries Res. 2006;40(2):124-9.Pubmed PMID: 16508269.

[55]. Paris S, Meyer-Lueckel H. Inhibition of caries progression by resin infiltration in situ. Caries Res. 2010;44(1):47-54.Pubmed PMID: 20090328.

[56]. Paris S, Meyer-Lueckel H, Kielbassa AM. Resin infiltration of natural caries lesions. J. Dent. Res. 2007 Jul;86(7):662-6.

[57]. Paris S, Hopfenmuller W, Meyer-Lueckel H. Resin infiltration of caries lesions: an efficacy randomized trial. J Dent Res. 2010 Aug;89(8):823-6.

[58]. Paris S, Schwendicke F, Keltsch J, Dörfer C, Meyer-Lueckel H. Masking of white spot lesions by resin infiltration in vitro. J Dent. 2013 Nov $1 ; 41(5): \mathrm{e} 28-34$

[59]. Martignon S, Ekstrand KR, Ellwood R. Efficacy of sealing proximal early active lesions: an 18-month clinical study evaluated by conventional and subtraction radiography. Caries Res. 2006;40(5):382-8.Pubmed PMID: 16946605.

[60]. Gomez SS, Basili CP, Emilson CG. A 2-year clinical evaluation of sealed noncavitated approximal posterior carious lesions in adolescents. Clin Oral Investig. 2005 Dec;9(4):239-43.Pubmed PMID: 16167153.

[61]. Schmidlin PR, Göhring TN, Sener B, Lutz F. Resistance of an enamel-bonding agent to saliva and acid exposure in vitro assessed by liquid scintillation. Dent Mater. 2002 Jun;18(4):343-50.Pubmed PMID: 11992913.

[62]. Vijayashree Priyadharsini J. In silico validation of the non-antibiotic drugs acetaminophen and ibuprofen as antibacterial agents against red complex pathogens. J Periodontol. 2019 Dec;90(12):1441-1448.Pubmed PMID: 31257588.

[63]. Pc J, Marimuthu T, Devadoss P, Kumar SM. Prevalence and measurement of anterior loop of the mandibular canal using CBCT: A cross sectional study. Clin. Implant Dent. Relat. Res. 2018 Apr 6;20(4):531-4.

[64]. Ramesh A, Varghese S, Jayakumar ND, Malaiappan S. Comparative estimation of sulfiredoxin levels between chronic periodontitis and healthy patients - A case-control study. J Periodontol. 2018 Oct;89(10):1241-1248.Pubmed PMID: 30044495.

[65]. Ramadurai N, Gurunathan D, Samuel AV, Subramanian E, Rodrigues SJ. Effectiveness of $2 \%$ Articaine as an anesthetic agent in children: randomized controlled trial. Clin Oral Investig. 2019 Sep;23(9):3543-50.

[66]. Sridharan G, Ramani P, Patankar S, Vijayaraghavan R. Evaluation of salivary metabolomics in oral leukoplakia and oral squamous cell carcinoma. J Oral Pathol Med. 2019 Apr;48(4):299-306.

[67]. Ezhilarasan D, Apoorva VS, Ashok Vardhan N. Syzygium cumini extract induced reactive oxygen species-mediated apoptosis in human oral squamous carcinoma cells. J Oral Pathol Med. 2019 Feb;48(2):115-121.Pubmed PMID: 30451321.

[68]. Mathew MG, Samuel SR, Soni AJ, Roopa KB. Evaluation of adhesion of Streptococcus mutans, plaque accumulation on zirconia and stainless steel crowns, and surrounding gingival inflammation in primary molars: randomized controlled trial. Clin Oral Investig. 2020 Sep;24(9):1-6.Pubmed PMID: 31955271

[69]. Samuel SR. Can 5-year-olds sensibly self-report the impact of developmental enamel defects on their quality of life? Int J Paediatr Dent. 2021 Mar;31(2):285-286.Pubmed PMID: 32416620.

[70]. R H, Ramani P, Ramanathan A, R JM, S G, Ramasubramanian A, et al. CYP2 C9 polymorphism among patients with oral squamous cell carcinoma and its role in altering the metabolism of benzo[a]pyrene. Oral Surg Oral Med Oral Pathol Oral Radiol. 2020 Sep;130(3):306-312.Pubmed PMID: 32773350.

[71]. Chandrasekar R, Chandrasekhar S, Sundari KKS, Ravi P. Development and validation of a formula for objective assessment of cervical vertebral bone age. Prog Orthod. 2020 Oct 12;21(1):38.Pubmed PMID: 33043408.

[72]. Vijayashree Priyadharsini J, Smiline Girija AS, Paramasivam A. In silico analysis of virulence genes in an emerging dental pathogen A. baumannii and related species. Arch Oral Biol. 2018 Oct;94:93-98.Pubmed PMID: 30015217. 